\title{
Erratum to: Urban harvests: food security and local fish and shellfish in Southcentral Alaska
}

Hannah L. Harrison ${ }^{1 *}$ and Philip A. Loring ${ }^{2}$

\section{Erratum to: Agric \& Food Secur (2016) 5:16 DOI 10.1186/s40066-016-0065-5}

$n . b$. The errors and associated corrections described in this document concerning the original manuscript were accountable to the production department handling this manuscript, and thus are no fault of the authors of this paper. Additionally, the online manuscript has now been updated with these corrections accordingly.

In the original publication of this article [1], Figure 2 and Figure 3 were inadvertently swapped. The figures can be found below with the correct legends. The original publication [1] has also been updated to reflect these changes (Figs. 2, 3).

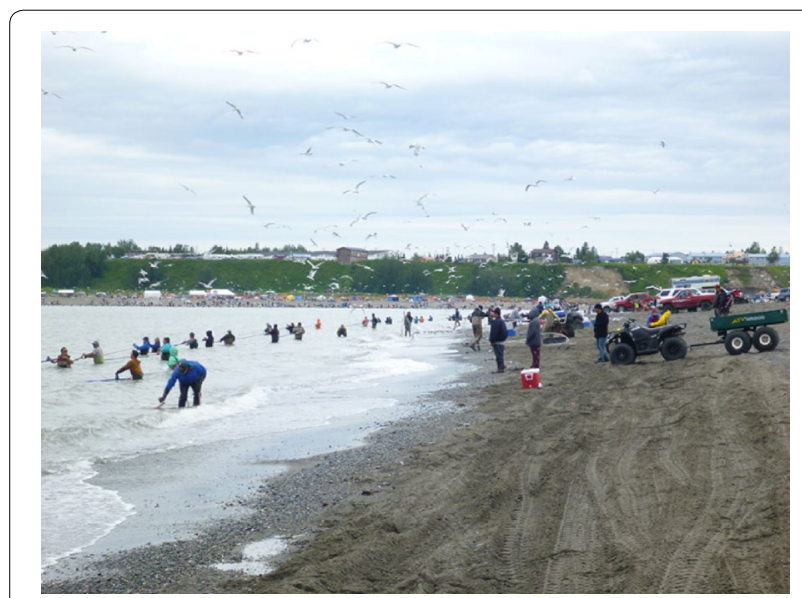

Fig. 2 Dipnet fishing. The Kenai River dipnet fishery is a popular annual event that draws thousands of local Alaskans

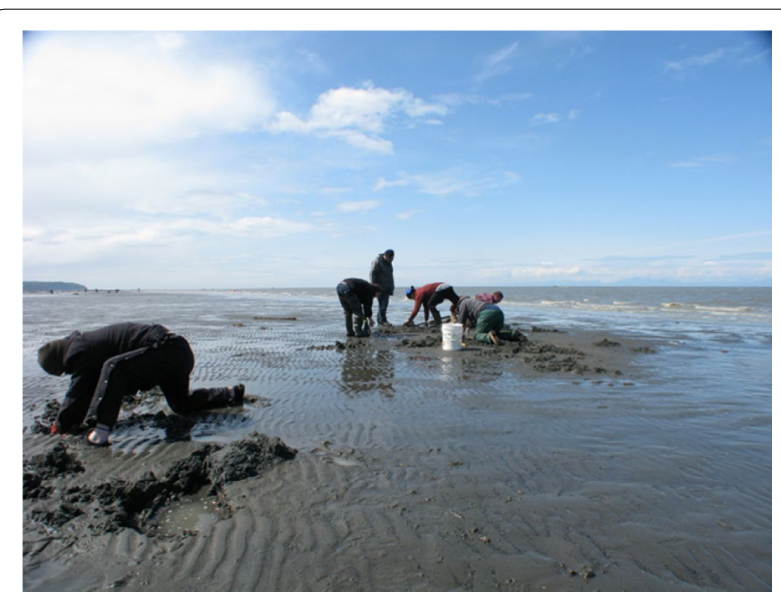

Fig. 3 Clam digging. Families dig for clams on Ninilchik Beach, Alaska

\section{Author details \\ ${ }^{1}$ Norwegian University of Life Sciences, Institute for Nature, Universitetstunet 3,1430 Ås, Norway. ${ }^{2}$ School of Environment and Sustainability, University of Saskatchewan, 117 Science Place, Saskatoon, SK S7J1X7, Canada.}

The online version of the original article can be found under doi:10.1186/s40066-016-0065-5.

Received: 15 August 2016 Accepted: 9 September 2016 Published online: 30 September 2016

\section{Reference}

1. Harrison HL, Loring PA. Urban harvests: food security and local fish and shellfish in Southcentral Alaska. Agric Food Secur. 2016;5:16. doi:10.1186/s40066-016-0065-5.

\footnotetext{
*Correspondence: hannah.harrison@nmbu.no

${ }^{1}$ Norwegian University of Life Sciences, Institute for Nature,

Universitetstunet 3, 1430 Ås, Norway

Full list of author information is available at the end of the article
} provided you give appropriate credit to the original author(s) and the source, provide a link to the Creative Commons license, and indicate if changes were made. The Creative Commons Public Domain Dedication waiver (http://creativecommons.org/ publicdomain/zero/1.0/) applies to the data made available in this article, unless otherwise stated. 